\title{
PRIMARY FIP1L1-PDGFR POSITIVE HYPEREOSINOPHILIC SYNDROME WITH UNUSUAL RHEUMATIC ONSET
}

\author{
Cosmin Sima ${ }^{1}$, Cristina Iosif $^{1}$, Constantin Busuioc ${ }^{1}$, Camelia Dobrea $^{2,3}$, Denisa Predețeanu ${ }^{1}$ \\ Daniel Coriu', Ana Manuela Crișan ${ }^{2,3}$ \\ "St. Mary" Clinical Hospital, Bucharest, Romania \\ ${ }^{2}$ Hematology and Bone Marrow Transplantation Department, Fundeni Clinical Institute, \\ Bucharest, Romania \\ "Carol Davila" University of Medicine and Pharmacy, Bucharest, Romania \\ Corresponding author: \\ Cosmin Sima, Internal Medicine and Rheumatology Department, "Saint Mary" Clinical \\ Hospital \\ 37-39 Ion Mihalache Blvd 011172, $1^{\text {th }}$ Sector, Bucharest, Romania \\ E-mail: cosminsima21@gmail.com
}

\begin{abstract}
Introduction. Hypereosinophilia (HE) is defined as an absolute eosinophil count $>1.5 \times 10^{9} / \mathrm{L}$ in the peripheral blood on two examinations separated in time by at least one month and/or pathologic confirmation of tissue HE. A hypereosinophilic syndrome (HES) is defined by the association of HE with eosinophil-mediated organ damage and/or dysfunction if other potential causes of them have been excluded.
\end{abstract}

Case report. We report a case of a 52-year-old woman admitted to Rheumatology Department for diffuse, highly intense (10/10) myalgia, associated with paravertebral, upper and lower limbs muscular edema and stiffness, having the onset of symptoms for about 4 months. During rheumatological evaluation, the patient developed posterior cervical diffuse pain with brachial irradiation associated with severe functional impotence reason for which it was indicated MRI of cervical spine. The blood count showed leucocytosis with hypereosinophilia. No evidence of Raynaud's phenomenon, cutaneous and muscular sclerosis or visceral involvement. All muscular groups and deep fascia appeared affected on the wholebody MRI and the findings were suggestive for Shulman's eosinophilic fasciitis or eosinophilic myopahty. All autoimmune, parasitic and allergic causes for myopathy were ruled out. Muscle tissue biopsy revealed high eosinophilic infiltrate predominantly in the deep muscular fascia, in the striated muscles and in the superficial dermis.

The patient received methyl-prednisolone pulse-therapy with a low-maintenance dose of prednisone which showed clinical improvement and normalized peripheral blood eosinophilia. A hematologic evaluation revealed high percentage of bone marrow eosinophil count which harbored FIP1L1-PDGFR alpha mutation and data was suggestive for the diagnosis of 


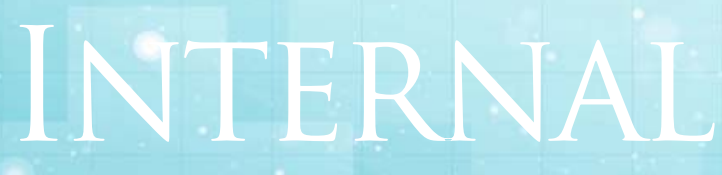

Clinical Cases.

myeloproliferative variant of HES syndrome along with Shulman's eosinophilic fasciitis for which Imatinib treatment was indicated.

Conclusion. The particularity of this case consists in the diagnosis of a myeloproliferative variant of HES with atypical presentation as a Shulman's eosinophilic fasciitis, a rheumatological condition. Even though initial symptoms were suggestive for a myopathy, it was difficult to establish the positive diagnosis without any obvious paraclinical data. Further investigations such as MRI and muscle biopsy were conclusive for the diagnosis of Shulman's eosinophilic fasciitis and clinical improvement was observed after corticosteroid treatment. Considering that after 4 months of evolution of the disease the patient did not present any atrophic lesions of the affected muscles and skin characteristic for Shulman's eosinophilic fasciitis the patient was referred to Hematology Department with the diagnosis of HES. Advanced exams established the hematological condition as primary FIP1L1-PDGFR positive HES which could benefit from tyrosine-kinase inhibitors treatment (Imatinib) known to induce in this situation improved clinical and paraclinical status.

Keywords: myopathy, eosinophilic fasciitis, hypereosinophilic syndrome, Imatinib.

\section{Rezumat}

Introducere. Hipereozinofilia (HE) se definește prin prezența în număr absolut a valorilor eozinofilelor în sângele periferic mai mari de 1,5 × 10 la două examinări efectuate la cel puțin o lună de zile diferență și/sau confirmarea patologică a HE tisulare. Sindromul hipereozinofilic (SHE) reprezintă asocierea dintre hipereozinofilie și lezarea/disfuncția dovedită de organ mediată de eozinofile, în condițiile excluderii altor posibile cauze potențial reversibile.

Prezentarea cazului. Vă prezentăm cazul unei paciente în vârstă de 52 de ani care se prezintă în Clinica de Reumatologie pentru mialgii difuze de intensitate extremă (10/10) însoțite de edem și contractură musculară la nivel paravertebral, la nivelul membrelor superioare și inferioare, având un debut al simptomelor de aproximativ 4 luni. Analizele uzuale relevă leucocitoză cu eozinofilie. Nu a existat dovada de fenomen Raynaud, scleroză cutanată și musculară sau afectare viscerală. În cursul evaluării reumatologice, pacienta a dezvoltat durere cervicală posterioară cu iradiere brahială însoțită de impotență funcțională severă, motiv pentru care $i$ se indică IRM de coloană cervicală. Examenul IRM de tip whole-body suprinde modificări edematoase la nivelul tuturor grupelor musculare și fasciilor profunde, constatările fiind sugestive pentru fasciită eozinofilică (sindromul Shulman) sau miopatie eozinofilică. Cauzele autoimune, parazitologice și alergologice ale miopatiei au fost excluse. Se 
practică biopsie musculară de la nivelul coapsei, iar examenul histopatologic decelează infiltrarea eozinofilică a mușchilor, fasciilor musculare și a dermului superficial.

Se inițiază puls-terapie cu metil-prednisolon, urmat de tratamentul de întreținere cu doză mică de prednison la domiciliu, cu remiterea simptomatologiei reumatologice și normalizarea eozinofiliei sangvine periferice. Consultul hematologic decelează prezența eozinofiliei medulare și prezența genei de fuziune FIP1L1-PDGFR alfa, datele fiind sugestive pentru diagnosticul de variantă mieloproliferativă a sindromului hipereozinofilic, asociată cu fasciită necrotică eozinofilică și se inițiază tratamentul cu Imatinib.

Concluzii. Particularitatea acestui caz constă în diagnosticul variantei mieloproliferative a sindromului hipereozinofilic, a cărui manifestare inițială atipică a fost de tip reumatologic, reprezentată de fasciita eozinofilică (sindrom Shulman). Chiar dacă simptomele inițiale sugerau diagnosticul de miopatie, diagnosticul a fost dificil de stabilit, în absența datelor paraclinice specifice. Investigațiile suplimentare de tip biopsie musculară și RMN au reușit să stabilească diagnosticul de sindrom Schulman, cu ameliorare clinică sub tratament glucocorticoid. Având în vedere că după 4 luni de evoluție pacienta nu prezenta leziuni atrofice ale musculaturii și țesutului cutanat, a fost îndrumată spre Clinica de Hematologie cu diagnosticul de SHE. Teste specifice au identificat cauza primară hematologică ca fiind SHE primar cu mutație FIP1L1-PDGFR pozitivă, ceea a putut beneficia de medicația de tipul inhibitorilor de tirozin-kinază (Imatinib), urmată de ameliorarea statusului clinico-paraclinic al pacientei.

Cuvinte-cheie: miopatie, fasciită eozinofilică, sindrom hipereozinofilic, Imatinib.

\section{Introduction}

Hypereosinophilia (HE) is defined as an absolute eosinophil count $(\mathrm{AEC})>1.5 \times 10^{9} / \mathrm{L}$ (or $>1500$ cells/microL) in the peripheral blood on two examinations separated in time by at least one month and/or pathologic confirmation of tissue HE.

A hypereosinophilic syndrome (HES) is defined by the association of $\mathrm{HE}$ with eosinophil-mediated organ damage and/or dysfunction when other potential causes for these have been excluded. However, there are multiple single organ-related eosinophilias. Advanced investigations such as muscle biopsy and whole-body MRI may be required. The diagnosis process should rule out other eosinophilic infiltration conditions. A hematologic evaluation should be performed, which can reveal, as in the case shown below, a myeloproliferative variant of hypereosinophilic syndrome.

\section{Case report}

We report the case of a 52-year-old Caucasian woman with a 4 months progressive onset of diffuse, very intense (10/10) myalgia. The pain was not influenced by the rest or physical effort and it did not have a nocturnal worsening. There were signs of diffuse painful muscular stiffness, including paravertebral, upper and lower limbs muscles with a reduced overall mobility. Other symptoms included bilateral inflammatory arthritis signs (rest-pain, edema, morning stiffness longer than 1 hour, reduced active and passive movements) of the smalls hand joints 


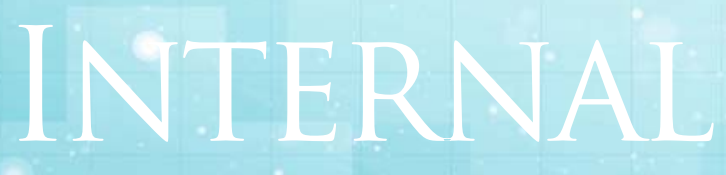

Clinical Cases.

(wrist, metacarpophalangeal, proximal interphalangeal) with a reduced overall mobility. Clinical examination showed muscular edema with rigidity and horizontal lines of atrophy of the upper and lower limbs. Cutaneous edema and induration with a „peau d'orange" appearance, affecting mainly the limbs, was present (Figure 1 ).

At admission to the Rheumatology Department, the patient appeared critically ill. Routine blood count showed leucocytosis (17580 cells $/ \mathrm{mm}^{3}$ ) with hypereosinophilia $\left(10340\right.$ cells $\left./ \mathrm{mm}^{3}\right), \mathrm{PCR}=60 \mathrm{mg} / \mathrm{L}(\mathrm{N}: 0-5$ $\mathrm{mg} / \mathrm{L}), \mathrm{LDH}=342 \mathrm{U} / \mathrm{L}(\mathrm{N}: 105-247 \mathrm{U} / \mathrm{L}), \mathrm{CK}=$ $45 \mathrm{U} / \mathrm{L}$ (N: 0-145 U/L).

Her personal medical history was unremarkable until two months ago when the patient described severe, progressive shortness of breath, acute onset palpitations and precordial pain. The patient was admitted to the hospital with BP $=135 / 70$ $\mathrm{mmHg}, \mathrm{HR}=35 \mathrm{bpm}$. Sinusal bradycardia and ST segment elevation in the anterior and inferior leads were observed on the ECG. The supplementary paraclinical investigations indicated in order to establish the etiology of severe bradycardia showed NT-pro-BNP = $1098 \mathrm{pg} / \mathrm{ml}$ ( $\mathrm{N}:<300 \mathrm{pg} / \mathrm{ml})$, D-dimers $=2.66 \mu \mathrm{g} / \mathrm{mL}(\mathrm{N}:<0.25 \mu \mathrm{g} / \mathrm{mL})$ and Troponin I $=1.5 \mathrm{ng} / \mathrm{L}(\mathrm{N}:<30 \mathrm{ng} / \mathrm{L})$. The diagnosis was transitory episode of sinusal bradycardia. Holter ECG revealed a minimum/maximum HR of 65 bpm/135 bpm, 5 ventricular and 8 supraventricular premature beats with no pauses longer than 2 seconds. The patient received atropine for treatment of severe symptomatic bradycardia. Cardiology evaluation recommended no specific treatment but further monitoring. Ten days prior to current admission, the patient described an urticaria-like, papular, pruriginous and edematous rash on the left forearm and left internal maleola which responded to oral antihistaminic treatment. For progressive diffuse onset of the myalgia, the patient was evaluated in Rheumatology Department and routine screening showed a normal WBC with eosinophilia $\left(1200 / \mathrm{mm}^{3}\right)$, high CRP $(13,18 \mathrm{mg} / \mathrm{dl})$, increased hepatic enzymes [TGO (153U/L) and TGP (188U/L)] and normal VSH and CK values. The parasitic and allergological evaluations ruled out any of suspected causes for eosinophilia and myalgia.

Due to onset of painful posterior cervical stiffness with bilateral brachial irradiating pain, a neurology consult was performed and the suspicion of cervical disc herniation was ruled out by a cervical MRI scan which revealed edematous infiltration of the muscular fascia. Further whole-body MRI scan was performed and edematous infiltration of the aponeurosis, deep muscle fascia and muscles in association with the neuro-vascular package thickening were observed. All MRI finding were suggestive for 


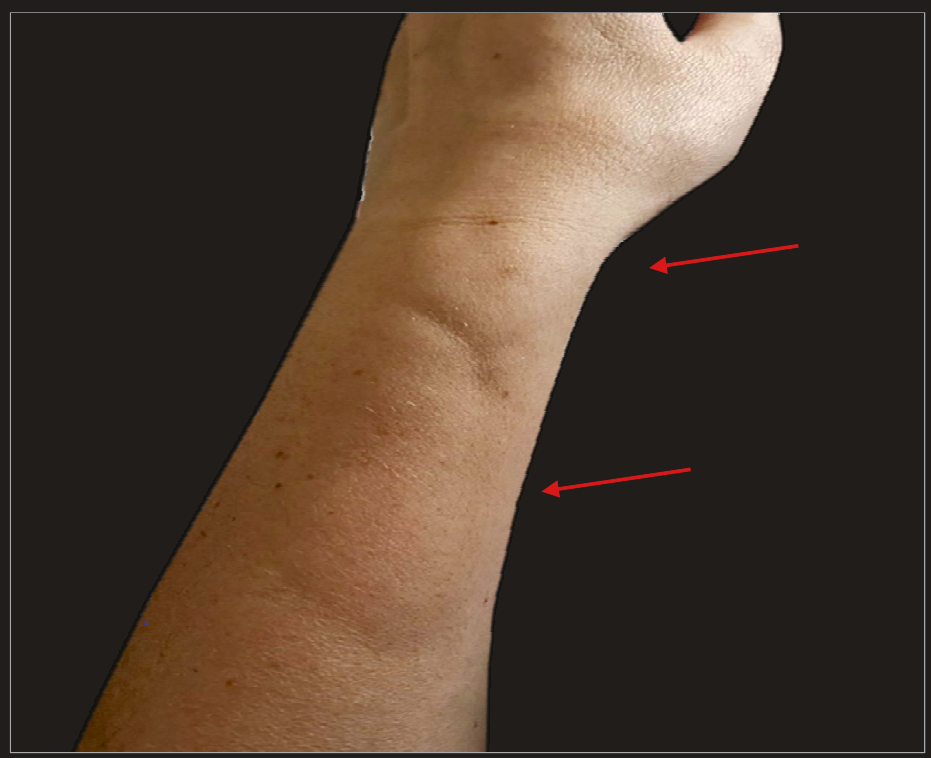

Figure 1. Left forearm: muscular edema with rigidity and horizontal lines of atrophy (black arrows)
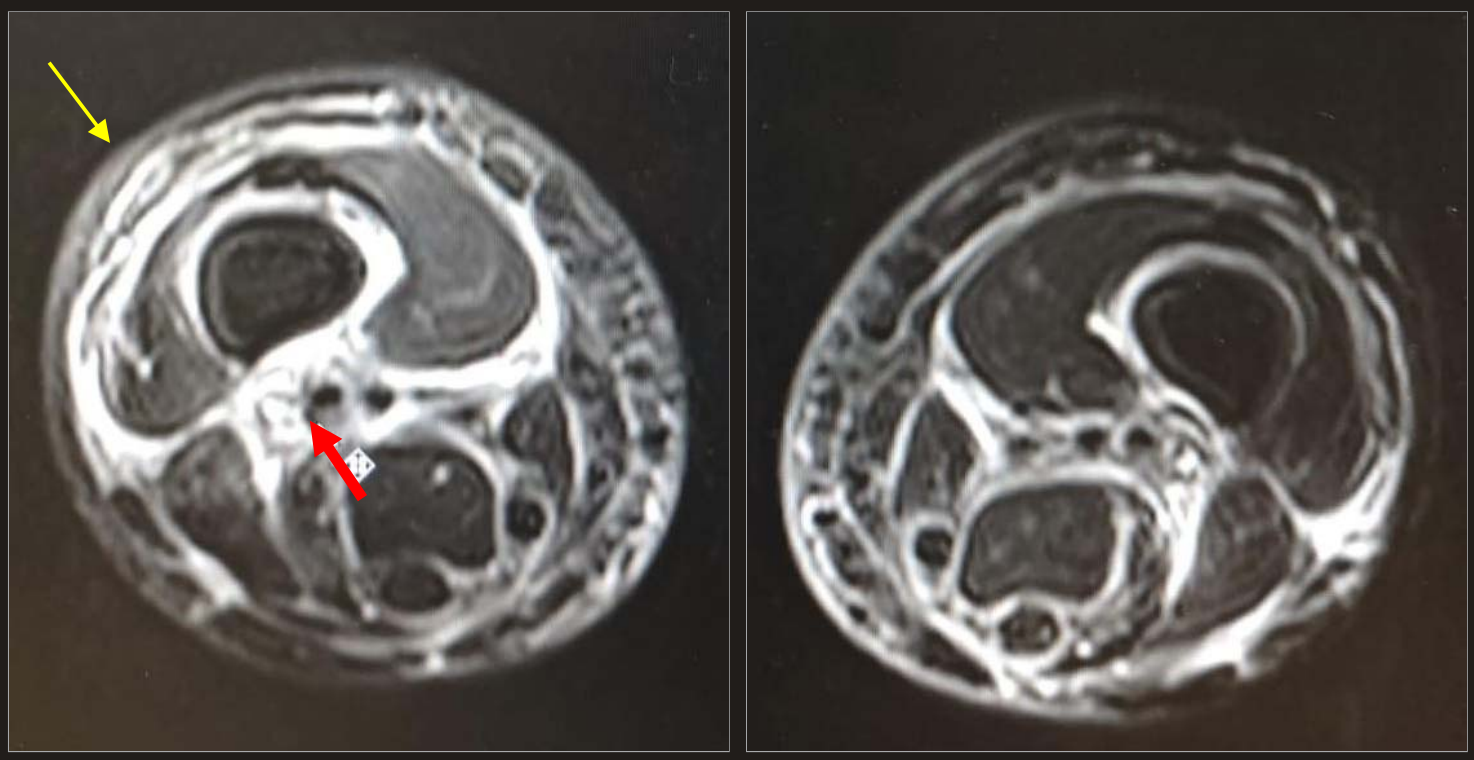

Figure 2. MRI whole body - Inferior limbs axial scanning: Hypointense T2 lesions (red arrow) including edematous infiltration and fluid accumulation not only in the profound system (muscles, muscle fascia, nervous-vascular adventitia, periosteum), but also in the superficial areas (subcutaneous tissue and superficial fascia - yellow arrow) 


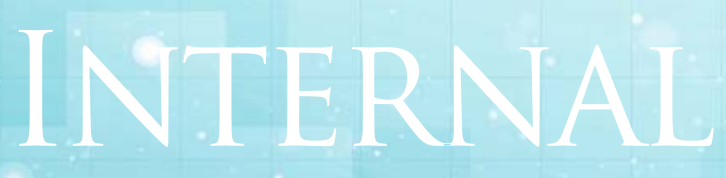

Clinical Cases

the eosinophilic fasciitis (Shulman's syndrome).

Polymyositis was excluded due to normal values of the muscular enzymes (specifically CK), absence of antibodies related to myositis, including anti-synthetasic antibodies profile (Mi2, Ku, Jo-1, SRP, PL-7, PL$12, E$, OJ) and electromyography which was inconclusive for a myopathy diagnosis. Systemic sclerosis seemed improbable in the presence of localized edema and cutaneous induration with the appearance of orangepeel-like texture, no signs of shiny, smooth surface skin being observed. Sclerodactyly and Raynaud's phenomenon were absent and the serology profile (Scl-70) was negative. Quadriceps muscular biopsy was performed and histopathology report showed extensive polymorphic infiltate represented by eosinophils, histiocytes and perivascular lymphocytes, suggestive for eosinophilic fasciitis. Immunochemistry report showed CD117 and tryptase positive in isolated mast cells; Tdt, CD25, CD3 and CD7 were negative. Previous sinus bradycardia episode alongside eosinophilia were suggestive for Loeffler endocarditis. Cardiac MRI scan showed no evidence of eosinophilic cardiomyopathy, but incipient hypertrophic cardiomyopathy lesion was present. Significant clinical improvement (pain, stiffness and general mobility) was obtained during corticosteroid treatment. A 3-days pulse therapy of daily methyl- prednisolone dose of $0.5 \mathrm{~g}$ was administered followed by prednisone $15 \mathrm{mg}$ b.i.d. with progressive reduction until stopping. Even if at discharge from the hospital the patient was in good condition and the number of total leucocytes and eosinophils were in normal range, the patient was referred for further hematological investigations.

At the hematology evaluation, the patient had no general symptoms, no palpable adenopathies or organomegaly and continued treatment with low doses of glucocorticoids (prednisone $15 \mathrm{mg} /$ day). The blood count showed mild leucocytosis with mild eosinophilia and no anemia and thrombocytopenia. The biochemical, coagulation, viral, bacterial and tumor screening were in normal ranges.

The molecular screening for JAK2 V617F, BCR$A B L 1$, core binding factor_(CBF) lesion, a platelet derived growth factor_(PDGFR) translocation (FIP1L1-PDGFRA and ETV6PDGFRB) and CKIT D816V mutation showed positivity for FIP1L1-PDGFRA. The whole body CT scans showed no tumor masses, adenopathies and organomegaly. Bone marrow exam showed normal bone marrow cellularity with increased granulocytic series due to increased eosinophils and eosinophil precursors.

The clinical and laboratory data were suggestive for the myeloproliferative variant of hypereosinophilic syndrome diagnosis along 

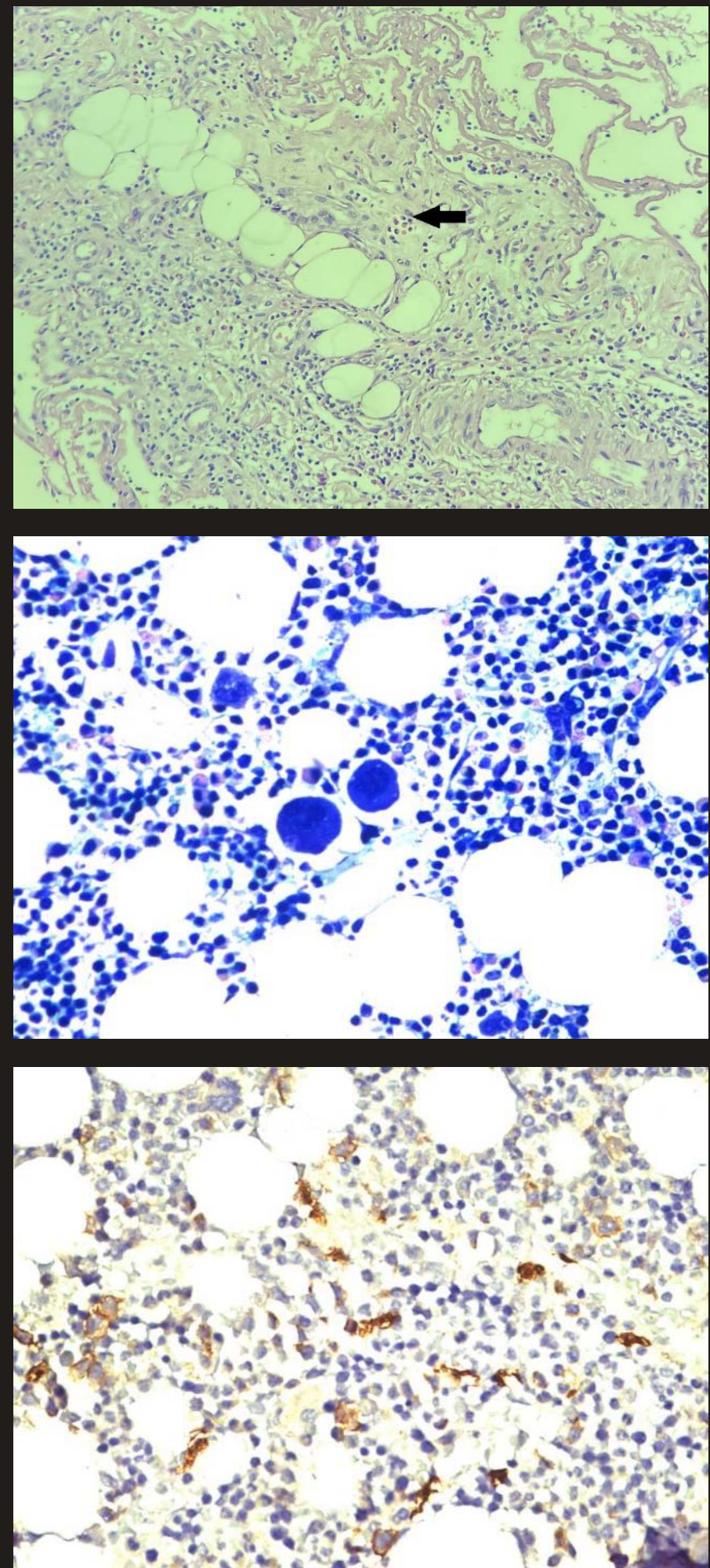

Figure 3. Muscle biopsy,

Hematoxylin \& eosin stain, ob. 40x: fascial polymorphic inflammatory infiltrate, mild eosinophilia, focal

microabscess (black arrow)

Figure 4. Bone marrow

biopsy, Giemsa stain, ob 40 x.: normocellular bone

marrow with mild eosinophilia (10-12\%)

Figure 5. Bone marrow biopsy, immunohistology stain for CD117, ob $40 x$ : areas with slightly increased of mast cells, some of are spindle-shaped (promyelocytes also expresses CD117) 


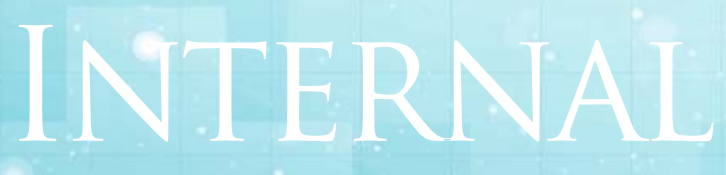

Clinical Cases.

with Shulman's eosinophilic fasciitis and the patient started daily $100 \mathrm{mg}$ Imatinib with clinical improvement. The patient will be seen by multidisciplinary team (rheumatologist, hematologist and cardiologist) to assess the response to Imatinib treatment.

\section{Discussion}

Eosinophilia ( $\leq 1500 / \mathrm{mm}^{3}$ ), hypereosinophilia $\left(\geq 1500 / \mathrm{mm}^{3}\right.$ ) and hypereosinophilic syndrome are signs for primary (mostly hematological) and secondary eosinophiliarelated diseases (peripheral causes) ${ }^{(1)}$.

Most of the primary causes have a genetic mutation or translocation. The most common chromosomal aberration is an interstitial deletion of chromosome $4 q 12$, which creates the FIP1L1-PDGFRA fusion from Fip1-like1 (FIP1L1) and platelet-derived growth factor receptor alpha (PDGFRA). The resultant protein, FIP1L1-PDGFRA, displays constitutive tyrosine kinase activity. Molecular testing for the FIP1L1-PDGFRA mutation should be performed on peripheral blood by performing fluorescence in situ hybridization (FISH) for the CHIC2 locus, which is located between the two fusion partners and therefore absent in the presence of the FIP1L1-PDGFRA fusion, or RTPCR for the fusion transcript. Hypereosinophilic syndromes (HES) are disorders marked by the sustained overproduction of eosinophils, associated with damage to one or more organs due to eosinophilic infiltration and mediator release. The signs and symptoms of HES result from overproduction of eosinophils, which infiltrate and damage various tissues. HE may result from clonal eosinophilic proliferation or from overproduction of eosinophilopoietic cytokines, such as interleukin 5 (IL-5). Clinically relevant subtypes include myeloproliferative variants, $\mathrm{T}$ cell lymphocytic variants, and familial eosinophilia. The secondary causes ${ }^{(7)}$ are more pleomorphic and may include parasitic, fungal or viral infections, autoimmune diseases, allergic disorders, Addison disease ${ }^{(9)}$, drug-induced hypereosinophilias, malignancies (both solid and hematological disorders) ${ }^{(1)}$, cholesterol embolism ${ }^{(8)}$ and multiple primary or secondary immunodeficiencies disorders.

Organ-related hypereosinophilias may occur and affect any tissue in the organism: eosinophilic endo and myocarditis, esophagitis, gastroenteritis, cystitis, fasciitis, miositis, cellulites, eosinophilic-myalgia syndrome, eosinophilic pneumonia(10) are the most frequently encountered.

Basic work-up should include: complete blood cells count $(C B C)$ with percentage and absolute number of eosinophils, biochemistry studies, bacterial screening (nasal smear, sputum, urine and stool examinations) and imagistic procedures (echocardiography, CT and MRI scans) may provide eosinophilic possible causes $^{(1)}$. To rule out acute/chronic 
myeloid/lymphoid neoplasms associated or not with eosinophilia, a hematological evaluation should be include bone marrow exam as well as FISH and molecular testing.

The diagnosis of HES will be supported by peripheral blood hypereosinophilia and the presence of the eosinophilic tissue infiltrate confirmed by tissue biopsy and immunohistopathology report ${ }^{(1)}$.

Eosinophilic fasciitis (Shulman syndrome) is characterized by a cutaneous and muscular fascia infiltration. This includes edema, erythema, tissue induration and thickening ${ }^{(2,4,5)}$. There are also peripheral "red flags" such as arthalgias/arthritis, myalgia/myopathy and neurological disorders such as carpal tunnel syndrome $^{(3)}$. Visceral involvement is rarely described $^{(2)}$.

Its etiology and pathogenesis are not fully understood. It is described as a border pathology, common association include autoimmune diseases (SLE, Sjögren syndrome, primary biliary cirrhosis) and bone marrow disorders - 10\% (myeloproliferative or myelodysplastic syndromes, eosinophilic leukemia, lymphomas, multiple myeloma, aplastic anemia) $)^{(2,3,6)}$. Systemic or localized sclerosis, scleroderma-like pathologies (scleromyxedema, nefrogenic systemic fibrosis or scleredema, eosinophilic-myalgia syndrome ${ }^{(1,2)}$ ) may mimic eosinophilic fasciitis.

Routine laboratory tests (CBC with eosinophilic percentage and absolute number along with increased non-specific muscular enzymes: LDH, GOT, GPT and normal CK values) required further investigations. EMG showed no myopathy pattern. For more accurate informations, whole-body MRI scan and tissue biopsy were performed and suggestive for the diagnosis of eosinophilic fasciitis but the cause was unknown. Autoimmune, parasitological and alergologic causes were ruled out by specific tests. Hematological evaluation was performed and supported the presence of a bone marrow neoplasm responsible for the rheumatologic presentation.

A variety of conditions which can be associated with blood or tissue eosinophilia and clinical manifestations of HES were ruled out: acute leukemias, myelodysplastic syndromes, lymphomas, chronic eosinophilic leukemias (CEL), KIT mutation-associated systemic mastocytosis with eosinophilia, drug hypersensitivity reactions, paraneoplastic syndromes and helminth infections.

The diagnosis of HES was based on cardiac, muscle and bone marrow involvement in the presence of blood and bone marrow eosinophilia and presence of FIP1L1-PDGFRA mutation at molecular testing. In our case, sinus bradycardia and conduction abnormalities could have been suggestive for restrictive cardiomyopathy and endomyocardial biopsy was necessary to rule out Loeffler syndrome. In particular, there are documented cases of transient episodes of bradycardia and conduction abnormalities associated with HES without any evidence of heart infiltration. This is due to a number of toxins released by the eosinophils granule substances: eosinophil-derived neurotoxin, cationic protein, major basic protein, reactive oxygen species and arachidonic acid derivatives. After a primary necrotic effect on the myocytes and endothelial cells of the conduction system, a secondary thrombotic and fibrotic phase develops, responsable for transient episodes of bradycardia ${ }^{(11,12,13)}$.

\section{Conclusions}

Our case report describes a medium-aged woman who begun investigations due to progressive fatigue, myalgia and diffuse cutaneous edema. First tests were suggestive for myopathy but the diagnosis was difficult to 
make without any obvious paraclinical criteria. Further investigations like MRI scan and deep muscle biopsy were suggestive for the diagnosis of Shulman's eosinophilic fasciitis associated with eosinophilic myopathy. After an empiric corticosteroid treatment, clinical improvement was observed. Further exams established the primary cause of the Shulman's eosinophilic fasciitis which was myeloproliferative variant of hypereosinophilic syndrome which could benefit from tyrosinekinase inhibitors treatment (Imatinib). On regular basis, the patient will be seen by multidisciplinary team (rheumatologist, hematologist and cardiologist) to assess the response to Imatinib treatment.

\section{Acknowledgements: none}

Conflict of interest disclosure: The authors declare that there are not conflicts of interest.

\section{References}

1. Peter Henning - Eosinophilic fasciitis, Medscape. Available from: https://emedicine.medscape.com/ article/329515-overview

2. Simon Helfgott, John Varga - Eosinophilic fasciitis, Uptodate. Available from: https://www.uptodate.com/ contents/eosinophilicfasciitis?search=Eosinophilic\%20fasc iitis\&source =search_result\&selectedTitle $=1 \sim 62 \&$ usage_t ype=default\&display_rank $=1$

3. Lakhanpal S, Ginsburg WW et al. - Eosinophilic fasciitis: clinical spectrum and therapeutic response in 52 cases, Semin Arthritis Rheum. 1988,17(4):221.

4. Rodnan GP, DiBartolomeo A, Medsger TA Jr Proceedings: Eosinophilic fasciitis. Report of six cases of a newly recognized scleroderma-like syndrome, Arthritis Rheum. 1975,18(5):525.

5. Bischoff, L., Derk, C. T. - Eosinophilic fasciitis: demographics, disease pattern and response to treatment: report of 12 cases and review of the literature. International Journal of Dermatology 2007,47(1):29-35

6. 6.. Doyle JA, Connolly SM, Hoagland HC - Hematologic disease in scleroderma syndromes. Acta Derm Venereol.1985,65(6):521.

7. Kovalszki A, Weller PF - Eosinophilia. Primary Care 2016, 43(4): 607-617

8. Zhang J, Zhang HY et al. - Anti-neutrophil cytoplasmic antibodies in cholesterol embolism: A case report and literature review. Experimental and Therapeutic Medicine 2016, 12(2): 1012-1018.

9. Montgomery $\mathrm{ND}$, Dunphy $\mathrm{CH}$ et al. -Diagnostic complexities of eosinophilia. Archives of Pathology \& Laboratory Medicine 2013, 137(2): 259-69

10. Valent $P$, Klion AD, Horny HP et al. - Contemporary consensus proposal on criteria and classification of eosinophilic disorders and related syndromes. The Journal of Allergy and Clinical Immunology 2012,130 (3): 607612.e9

11. Sohail Hasan - Loeffler endocarditis, Medscape. Available from: https://emedicine.medscape.com/ article/155340-overview\#a5

12. Cunningham K, Davies RA et al - Pathologic quiz case: a young woman with eosinophilia and heart failure. Primary hypereosinophilic syndrome with loeffler endocarditis. Arch Pathol Lab Med. 2005, 129(1):e29-30 13. Gleich GJ, Frigas $E$ et al.- Cytotoxic properties of the eosinophil major basic protein. J Immunol. 1979, 123(6):2925-7 